\title{
Natural mortality factors of tomato leafminer Tuta absoluta in open-field tomato crops in South America
}

\author{
Leandro Bacci, ${ }^{a}{ }_{\odot}$ Ézio M Silva, ${ }^{b}$ Gerson A Silva, ${ }^{{ }^{*}}{ }^{*}$ Laércio J Silva, ${ }^{d}$ Jander F \\ Rosado, ${ }^{e}$ Richard I Samuels ${ }^{\mathrm{c}}$ and Marcelo C Picanço ${ }^{\mathrm{e}}$
}

\begin{abstract}
BACKGROUND: Little importance has been given to the role of natural mortality factors (biotic and abiotic) in the regulation of tomato leafminer Tuta absoluta (Lepidoptera: Gelechiidae) populations. The present study determined the action of mortality factors on T. absoluta populations infesting cultivated tomato crops. Eighty ecological life tables for T. absoluta in field cultivated tomato plants were constructed and analyzed.
\end{abstract}

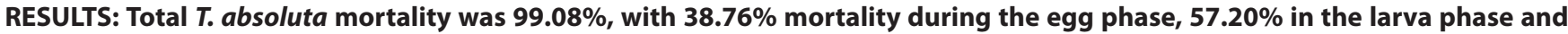
$3.12 \%$ in the pupal phase. The main mortality factors during the egg stage were predation, parasitism and egg inviability. In the larval stage, the main mortality factors were predation, parasitism, entomopathogenic agents and physiological disorders. In the pupal stage, the main mortality factor was predation. The larvae of the third and fourth instar were more susceptible to the action of mortality factors and the predatory wasp, Protonectarina sylveirae, was the main insect predator of these larvae.

CONCLUSIONS: The T. absoluta population is regulated under field conditions by the action of natural enemies of the larvae. The predatory wasp $P$. sylveirae is very important in the regulation of $T$. absoluta populations in open-field tomato crops in Brazil. (c) 2018 Society of Chemical Industry

Keywords: ecological life table; tomato leafminer; natural enemy; critical phase

\section{INTRODUCTION}

The tomato leafminer Tuta absoluta (Polvony) (Lepidoptera: Gelechiidae) is currently the main lepidopteran pest of tomatoes (Solanum lycopersicum L.) worldwide. This is due to the damage it causes to leaves, shoots, flowers, and fruits of tomato plants ${ }^{1-3}$ and its high capacity for dispersal. ${ }^{4}$ It was first documented in Brazil at the beginning of the 1980s and is now prevalent in all states of the country. ${ }^{2,5}$ A similar phenomenon occurred in Europe where T. absoluta was first reported in Spain in 2006, and has since spread to many other countries in Europe, Africa and Asia., ${ }^{4,6-8}$

Tuta absoluta larvae are leafminers and bore into the branches and fruits of solanaceous plants. ${ }^{9,10}$ Within these structures, the larvae are less exposed to natural enemies, climatic elements and insecticides. The endophytic behavior of the larvae decreases the effectiveness of insecticides, because many insecticides present low levels of translocation in tomato plants. ${ }^{2,11}$ Brazilian farmers carry out around 60 to 80 insecticide applications per season in an attempt to control T. absoluta in tomato crops grown in the field. Despite this heavy insecticide use, failure to control this pest has been observed in several tomato producing regions. The main causes of this failure are selection for insecticide resistant populations, the impact of pesticides on natural enemies and poor spray technology. ${ }^{12,13}$

A lack of knowledge concerning the role of natural enemies (top-down force), climatic factors and plant defenses (bottom-up force) in insect pest population dynamics can lead to farmers focusing on insecticide use as the main mechanism for reducing insect pest populations in crops, while overlooking the importance of natural factors. Several indigenous enemies were reported in tomato crops which cause mortality of T. absoluta. In particular, insects predators (Coccinellidae, Formicidae, Miridae, Nabidae and Vespidae), parasitoids (Braconidae, Elasmidae, Eulophidae, Ichneumonidae, Pteromalidae and Trichogrammatidae) and entomopathogenic microorganisms. ${ }^{4,7,14-18}$

Natural mortality factors help to regulate pest populations, reduce losses caused by pests in crops, are environmentally safe

\footnotetext{
Correspondence to: GA Silva, Laboratório de Entomologia e Fitopatologia Universidade Estadual Norte Fluminense Darcy Ribeiro (UENF), Avenida Alberto Lamego 2000, Campos dos Goytacazes, Rio de Janeiro, 28035-200, Brazil. E-mail: silva.gersonadriano@gmail.com

a Departamento de Engenharia Agronômica, Universidade Federal de Sergipe, São Cristóvão, Brazil

b Departamento de Ciências Agrárias, Universidade Federal de Viçosa, Viçosa, Brazil

c Laboratório de Entomologia e Fitopatologia, Universidade Estadual Norte Fluminense Darcy Ribeiro, Rio de Janeiro, Brazil

d Departamento de Fitotecnia, Universidade Federal de Viçosa, Viçosa, Brazil

e Departamento de Entomologia, Universidade Federal de Viçosa, Viçosa, Brazil
} 
and have little or no impact on production costs. ${ }^{19}$ Ecological life tables can provide important information about the mortality factors affecting insect population dynamics, allowing the identification and quantification of mortality caused by specific factors and the life-stages that determine insect pest population size. ${ }^{14,20-23}$ Mortality factors may act during all insect life-stages, with the eggs and immature stages being the most susceptible.

The present study was designed to investigate the impact of natural mortality factors on a T. absoluta population by building ecological life tables. We carried out the experiments in a major tomato producing region of Brazil. Mortality factors were checked daily, beginning at sunrise and ending at sunset. The results obtained will be very important for the planning of future integrated pest management programs.

\section{MATERIAL AND METHODS}

This study was carried out in the experimental area of the Federal University of Viçosa $\left(20^{\circ} 48^{\prime} 45^{\prime \prime} \mathrm{S}\right.$; $42^{\circ} 56^{\prime} 15^{\prime \prime} \mathrm{W}$; altitude $672 \mathrm{~m}$; tropical climate), in the State of Minas Gerais, Brazil. The S. licopersicum variety of tomato, locally known as 'Santa Clara,' was used. Tomato plants were cultivated in open fields during 2 years, the interval between tomato planting was 3 months. Each crop occupied a total area of $864 \mathrm{~m}^{2}$ and this area was divided into four blocks $\left(180 \mathrm{~m}^{2}\right)$. Each block consisted of 12 rows of plants, containing 30 tomato plants with a spacing of $0.5 \mathrm{~m}$ between plants and $1 \mathrm{~m}$ between rows. Standard agronomic practices for tomatoes were applied to all blocks, with pesticide spraying for insect and disease control not carried out.

\subsection{Cohort establishment}

The insects used in this study were from a T. absoluta colony maintained in the Integrated Pest Management Laboratory of the Federal University of Viçosa. Thirty T. absoluta adults (2 days old) were caged with tomato plant branches using netting bags (size: $30 \mathrm{~cm} \times 40 \mathrm{~cm}$ ). After a $24 \mathrm{~h}$ period, most of the adults had died and the bags were removed and any surviving adults were killed by crushing. The egg cohorts were quantified and mapped through the schematic drawing of tomato leaves. The number of eggs per plant was 150 and any excess eggs were removed using a brush (size 1).

Egg mortality was calculated from the number of T. absoluta eggs originally laid on the leaves when compared to the number of 1st instar larvae. The second, third and fourth larval stages were obtained from the laboratory colony $\left[25 \pm 0.5^{\circ} \mathrm{C}\right.$, relative humidity

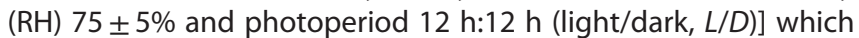
had been maintained on tomato plants (Santa Clara variety) and transferred with a brush to a leaf in the middle portion of each tomato plant in the field. A total of 25 larvae of each instar (five larvae per leaf) were transferred to tomato plants. This density is in agreement with that observed naturally in the field. ${ }^{24}$

For pupal life tables, 30 pupae from the laboratory colony were placed in plastic pots $(10 \mathrm{~cm}$ diameter $\times 7 \mathrm{~cm}$ high), filled with sand, and then the pupae were covered with a thin layer of sand. The pots were then buried next to the base of the tomato plants, such that the top edge of the pot was at ground level. The pots were maintained in the field for 6 days. ${ }^{25}$

\subsection{Assessment of mortality factors in field conditions}

Natural mortality of T. absoluta eggs, larvae, and pupae was monitored daily from 6:00 to $18: 00 \mathrm{~h}$. The mortality in the field caused by predators and rainfall was determined. Mortality resulting from parasitism, entomopathogens (fungi, bacteria, or viruses), egg inviability, and physiological disturbances (larvae that died showing signs of predation and disease symptoms) were determined in the laboratory. Dead larvae with signs or symptoms of fungal and bacterial diseases were evaluated according to symptomatology. ${ }^{18}$ Samples from diseased larvae were collected and taken to the laboratory and placed in Petri dishes (diameter of $9 \mathrm{~cm}$ ) containing specific culture medium for each pathogen group. Egg and larval mortality caused by rainfall was determined by the difference in egg numbers and living larvae before and after each rainfall. ${ }^{23}$ Mortality caused by rainfall was recorded immediately after the event, through the observation of the presence of water inside the mine. Eggs that disappeared between two consecutive evaluations were considered to have been subject to predation. ${ }^{18,23}$ The presence of putative predators on each leaf was recorded, and specimens were collected and maintained in Eppendorf tubes containing $70 \%$ ethanol for subsequent identification.

Eggs that did not hatch were transferred to test-tubes to observe the possible emergence of parasitoids or the occurrence of egg inviability.

The first, second, third and fourth instar larvae that survived to the end of the larval developmental stage were taken to the laboratory and transferred to tomato leaves for observation of T. absoluta adult emergence or possible parasitoid emergence. Pupal predation frequencies were calculated from the difference between the initial number of pupae placed in the pots and the number of pupae remaining at the end of the experiment. The remaining pupae were transferred to test tubes and placed in a temperature and humidity controlled environment $\left[25 \pm 0.5^{\circ} \mathrm{C}\right.$, $\mathrm{RH} 75 \pm 5 \%$ and photoperiod $12 \mathrm{h:12} \mathrm{h}(L: D)]$ for 30 days to observe the emergence of $T$. absoluta adults and parasitoids. The pupae that did not become adults and that had not been parasitized, were classified as dead from the effects of rainfall or possible physiological disorders.

Parasitoid specimens were identified by Dr Angélica Maria Penteado Martins Dias of the Federal University of São Carlos, Brazil. Hemipteran predators were identified by Dr Paulo Sérgio Fiuza Ferreira and fungi were identified by Dr Simon Luke Elliot, both from the Federal of University of Viçosa (UFV), Brazil. Coleopteran predators were identified by Dr Ayr de Moura Bello.

\subsection{Analyses of life tables}

Tuta absoluta life tables were constructed using the methodology of Southwood and Henderson. ${ }^{26}$ The life tables presented T. absoluta developmental stages and mortality factors, number of individuals at the start of the experiment (Ix), mortality at each stage $(\mathrm{dx})$ and the apparent percent mortality (100qx). The 100qx was calculated by the formula:

$$
100 \mathrm{qx}=[\mathrm{dx} / \mathrm{lx}] / 100
$$

where $I_{0}=$ number of eggs at the beginning of the life table evaluation; $I_{0}$ was transformed to 10000 .

The net reproductive rate $\left(R_{0}\right)$ was obtained by dividing the number of expected eggs in the next generation (number of adult survivors in the actual cohort $\times$ sex ratio $\times$ adult fertility) by the total number of eggs (10 000) present at the beginning of each cohort. We considered the sex ratio as equal to 0.5973 and fecundity as 183 eggs/female. ${ }^{27}$

The critical phase, critical stage and key mortality factors of $T$. absoluta were determined by correlation and linear regression 
analyses using specific stage mortality $(k)$ and total mortality $(K=P k)$ at $P<0.05$. The value of $k$ was obtained by the formula $k=\log (100 \mathrm{qx})$. The critical phase, critical stage and key mortality factors were considered as those which presented a significant correlation $(P<0.05)$ with total mortality, producing a regression curve showing the highest inclination coefficient $(P<0.05)$, and having the greatest similarity $\left(R^{2}\right)$ with total mortality. ${ }^{18,23,25,26}$

\section{RESULTS}

During the observation of $80 \mathrm{~T}$. absoluta generations, we found that for 10000 eggs only $91.28 \pm 18.39$ resulted in adults. This represents a survival rate of only $0.92 \%$. The apparent mortality rates for the egg, larval and pupal stages were 38.76, 93.41 and $77.4 \%$, respectively. During the first, second, third and fourth instar larval stages, mortality was $36.66,40.82,63.04$ and $52.40 \%$, respectively. The population growth rate was approximately one $\left(t_{1,158}=0.012, P=0.99\right)$.

Several factors contributed to T. absoluta mortality at different life stages. Coleoptera, Hemiptera, Hymenoptera, Neuroptera and spiders (Araneae) were observed to be predators of immature stages of $T$. absoluta. The principal predators observed were the beetle Oxypodini sp. (Coleoptera: Staphylinidae), bugs of the genus Orius sp., Lasiochilus sp. (Heteroptera: Anthocoridae), Annona bimaculata Distant, and Hyaliodocoris insignis (Stal.) (Heteroptera: Miridae). The main Hymenopteran predators were the wasps Brachygastra lecheguana (Latr.), Polybia scutellaris (White), Protonectarina sylveirae (Saussure) (Hymenoptera: Vespidae) and predatory ants of the genus Solenopsis sp. (Hymenopetra: Formicidae). In the order Neuroptera, the main representative predators were green lacewing larvae of the genus Chrysoperla sp. (Chrysopidae) (Table 1).

The most important parasitoids were Trichogramma sp. (Hymenoptera: Trichogrammatidae) for eggs, Bracon sp. and Earinus sp. (Hymenoptera: Braconidae) for third and fourth instar larvae and Pseudapanteles sp. (Hymenoptera: Braconidae) for pupae (Table 1).

\subsection{Phase and critical stage for $T$. absoluta mortality}

The larval mortality curve was unique showing the greatest similarity to total mortality of T. absoluta $(r=0.98 ; P<0.001)$ (Fig. 1(A)). The larval mortality curves of the second $(r=0.75 ; P<0.001)$, third $(r=0.93 ; P<0.001)$ and fourth $(r=0.92 ; P<0.001)$ instars correlated significantly with total larval mortality (Fig. 1(B)). The curves for third and fourth instar larvae showed higher angular coefficients and were the most highly correlated with total mortality of the larval stage. The overlapping confidence intervals of their angular coefficients demonstrated that the mortality curves of third and fourth instar larvae were statistically similar (Fig. 1(C)). The critical phase of T. absoluta was shown to be the larval stage and the critical stages for mortality were third and fourth instar larvae. The key mortality factor was predation and the critical component of this mortality was predation by the wasp $P$. sylveirae.

\subsection{Key-factors and critical components of T. absoluta mortality}

In third $(r=0.95 ; P<0.001)$ and fourth $(r=0.90 ; P<0.001)$ instar larvae, only mortality caused by predation correlated significantly with the total mortality (Figs $2(A)$ and $3(A)$ ). Predation by the wasp $P$. sylveirae was the main mortality component during the third and fourth instars. The mortality curve observed as a result of
P. sylveirae predation significantly correlated with total predation observed during these instars (Figs 2(B) and 3(B)).

In summary, the critical phase of the $T$. absoluta life cycle was the larval stage, and within that stage the critical stages were the third and fourth instar larval stages. The key mortality factor was predation and the critical mortality component was predation by the wasp P. sylveirae.

\section{DISCUSSION}

The information generated by this study demonstrated the importance of biotic and abiotic factors in regulating T. absoluta population dynamics. Knowledge of these factors is essential for the implementation of integrated pest management programs for the control of T. absoluta in tomato crops.

The population of T. absoluta remained constant over 80 generations $\left(R_{0}=1\right)$ in tomato plants. This equilibrium was the result of climatic factors and bottom-up and top-down factors affecting the pest population dynamics. The observation of the action of bottom-up factors in herbivores is most evident in non-domesticated plants. ${ }^{28}$ The defense compounds of tomato plants may have been responsible for unviable eggs and the physiological disorders seen in larvae and pupae. These compounds can act on the physiological processes of insects, either reducing their biological performance or causing mortality. ${ }^{29,30}$

The top-down factors were the most important in reducing the T. absoluta population. These factors are important in the population dynamics of arthropod pests in agro-ecosystems. ${ }^{14,18,31}$ In these situations, the simplification of environmental factors in monocultures creates favorable conditions for the establishment of phytophagous insect populations in host plants. By contrast, the high population density of phytophagous insects may support the occurrence and maintenance of natural enemies (predators, parasitoids and entomopathogens). ${ }^{18,23,32-34}$

Third and fourth instar larvae were shown to be the critical stages for T. absoluta mortality. These results are different from those obtained by Miranda et al., ${ }^{14}$ where the critical stages for T. absoluta were found to be the first and second instar larval stages. Miranda et $\mathrm{al}^{14}$ applied insecticides during the study with smaller larvae being more susceptible to insecticides than larger larvae. This was probably due to their higher specific surface area resulting in greater exposure to these products. Additionally, insecticides are likely to have an adverse effect on $T$. absoluta natural enemies, ${ }^{35}$ masking the action of these organisms in larger larvae. Larger larvae represent a greater reward for predators and are easier to find on plants than smaller larvae. ${ }^{36}$ Corroborating our results, Gonring et al. ${ }^{33}$ observed that third and fifth instar larvae were the critical mortality stages for Diaphania nitidalis and the key mortality factor was predation by the wasp Polybia ignobillis. Although leaf mining behavior protects T. absoluta larvae from the action of natural enemies, confinement in these spaces may leave larvae vulnerable to the action of natural enemies that are capable of locating the larvae inside the mines and breach the protection of the mine to prey on the larva. The predation of larger larvae in open-field tomato crops has also been reported in Iran, Spain, Egypt, Jordan, France, Israel, Turkey, Marocco, Italy and Tunisia, countries where T. absoluta is considered an invasive pest. ${ }^{37,38}$

Ecological life tables provide important information about the factors that regulate the population dynamics of phytophagous insects. ${ }^{18,22,23}$ Using this tool, it is possible to identify the critical phase and main factors that cause insect mortality in the environment. ${ }^{19}$ Although mortality factors may act on all 
Table 1. Ecological life table for Tuta absoluta in tomato plants, Viçosa county, State of Minas Gerais

\begin{tabular}{|c|c|c|c|}
\hline Stages/mortality factors & Lx & $d x$ & $100 q x$ \\
\hline Eggs & $10000.00 \pm 0.00$ & $3876.24 \pm 183.88$ & $38.76 \pm 1.84$ \\
\hline Rainfall & & $502.12 \pm 82.28$ & $5.02 \pm 0.82$ \\
\hline Predation & & $1603.40 \pm 138.05$ & $16.03 \pm 1.38$ \\
\hline Parasitism & & $818.44 \pm 126.25$ & $8.19 \pm 1.26$ \\
\hline Trichogramma sp. & & $818.44 \pm 126.25$ & $8.19 \pm 1.26$ \\
\hline Inviability & & $952.28 \pm 95.48$ & $9.52 \pm 0.95$ \\
\hline First instar larva & $6123.76 \pm 183.90$ & $2244.72 \pm 179.66$ & $36.66 \pm 1.80$ \\
\hline Rainfall & & $228.69 \pm 37.55$ & $3.74 \pm 0.38$ \\
\hline Predation & & $1843.81 \pm 148.46$ & $30.11 \pm 1.48$ \\
\hline Physiological distubance & & $172.22 \pm 32.40$ & $2.81 \pm 0.32$ \\
\hline Second instar larva & $3879.05 \pm 165.34$ & $1583.49 \pm 144.05$ & $40.82 \pm 1.44$ \\
\hline Rainfall & & $0.00 \pm 0.00$ & $0.00 \pm 0.00$ \\
\hline Predation & & $1544.03 \pm 144.10$ & $39.80 \pm 1.44$ \\
\hline Bugs predators & & $691.20 \pm 63.88$ & $17.82 \pm 0.64$ \\
\hline Protonectarina sylveirae & & $846.42 \pm 154.09$ & $21.82 \pm 1.54$ \\
\hline Chrysoperla externa & & $6.41 \pm 6.41$ & $0.17 \pm 0.06$ \\
\hline Physiological disturbance & & $26.48 \pm 9.46$ & $0.68 \pm 0.09$ \\
\hline Pathogens & & $12.98 \pm 8.66$ & $0.33 \pm 0.09$ \\
\hline Bacteria & & $1.65 \pm 1.65$ & $0.04 \pm 0.02$ \\
\hline Fungi & & $11.33 \pm 8.53$ & $0.29 \pm 0.09$ \\
\hline Third instar larva & $2295.56 \pm 153.92$ & $1447.22 \pm 116.94$ & $63.06 \pm 1.17$ \\
\hline Rainfall & & $133.98 \pm 32.16$ & $5.84 \pm 0.32$ \\
\hline Predation & & $890.14 \pm 115.62$ & $38.78 \pm 1.16$ \\
\hline Bugs predators & & $13.23 \pm 6.64$ & $0.58 \pm 0.07$ \\
\hline Protonectarina sylveirae & & $872.32 \pm 114.84$ & $38.00 \pm 1.15$ \\
\hline Brachygastra lecheguana & & $3.40 \pm 2.47$ & $0.15 \pm 0.02$ \\
\hline Spiders & & $1.20 \pm 0.87$ & $0.05 \pm 0.01$ \\
\hline Physiological disturbance & & $32.52 \pm 13.76$ & $1.42 \pm 0.14$ \\
\hline Diseases & & $17.18 \pm 7.65$ & $0.75 \pm 0.08$ \\
\hline Bacteria & & $13.00 \pm 7.40$ & $0.57 \pm 0.07$ \\
\hline Fungi & & $4.18 \pm 2.26$ & $0.18 \pm 0.02$ \\
\hline Parasitism & & $373.40 \pm 74.66$ & $16.27 \pm 0.75$ \\
\hline Bracon sp. & & $371.79 \pm 74.67$ & $16.20 \pm 0.75$ \\
\hline Earinus sp. & & $1.61 \pm 1.13$ & $0.07 \pm 0.01$ \\
\hline Fourth instar larva & $848.34 \pm 106.40$ & $444.55 \pm 53.26$ & $52.41 \pm 0.53$ \\
\hline Rainfall & & $19.81 \pm 5.30$ & $2.34 \pm 0.05$ \\
\hline Predation & & $180.74 \pm 34.88$ & $21.31 \pm 0.35$ \\
\hline Bugs predators & & $3.90 \pm 2.39$ & $0.46 \pm 0.02$ \\
\hline Protonectarina sylveirae & & $174.12 \pm 34.31$ & $20.53 \pm 0.34$ \\
\hline Brachygastra lecheguana & & $0.48 \pm 0.33$ & $0.06 \pm 0.00$ \\
\hline Polybia scutellaris & & $0.54 \pm 0.38$ & $0.06 \pm 0.00$ \\
\hline Oxypodini sp. & & $1.56 \pm 1.56$ & $0.18 \pm 0.02$ \\
\hline Spiders & & $0.13 \pm 0.13$ & $0.02 \pm 0.00$ \\
\hline Physiological disturbance & & $10.75 \pm 4.26$ & $1.27 \pm 0.04$ \\
\hline Diseases & & $8.55 \pm 3.28$ & $1.01 \pm 0.03$ \\
\hline Bacteria & & $1.23 \pm 1.18$ & $0.14 \pm 0.01$ \\
\hline Fungi & & $7.33 \pm 3.09$ & $0.87 \pm 0.03$ \\
\hline Parasitism & & $224.70 \pm 44.32$ & $26.49 \pm 0.44$ \\
\hline Bracon sp. & & $218.80 \pm 43.94$ & $25.79 \pm 0.44$ \\
\hline Earinus sp. & & $5.90 \pm 3.28$ & $0.70 \pm 0.03$ \\
\hline Conura sp. & & $0.001 \pm 0.001$ & $0.00 \pm 0.00$ \\
\hline
\end{tabular}


Table 1. Continued

Stages/mortality factors

Lx

$d x$

$100 q x$

$\begin{array}{ll}\text { Pupa } & 403.80 \pm 73.85\end{array}$

$312.52 \pm 58.87$

$77.39 \pm 0.59$

Rainfall

$3.77 \pm 2.60$

$0.93 \pm 0.03$

Predation

$227.03 \pm 43.89$

Formicidae

$227.03 \pm 43.89$

$56.22 \pm 0.44$

Physiological disturbance

$76.42 \pm 21.77$

$56.22 \pm 0.44$

Parasitism

$5.30 \pm 2.72$

$18.93 \pm 0.22$

Pseudapanteles sp.

$5.30+2.72$

$1.31 \pm 0.03$

$1.31+0.03$

Adults

Total mortality

$91.28 \pm 18.39$

$R_{0}$

$99.08 \%$

$0.99 \pm 0.19$

In the table, Ix corresponds to the number of insects alive at the beginning of each stage ( \pm standard error), $\mathrm{dx}$ is the number of insects killed by a factor ( \pm standard error) for each stage, $100 \mathrm{qx}$ is the apparent mortality percentage or the percentage of insects killed by a factor during a specific life stage and $R_{0}$ is net reproductive rate.

(A)

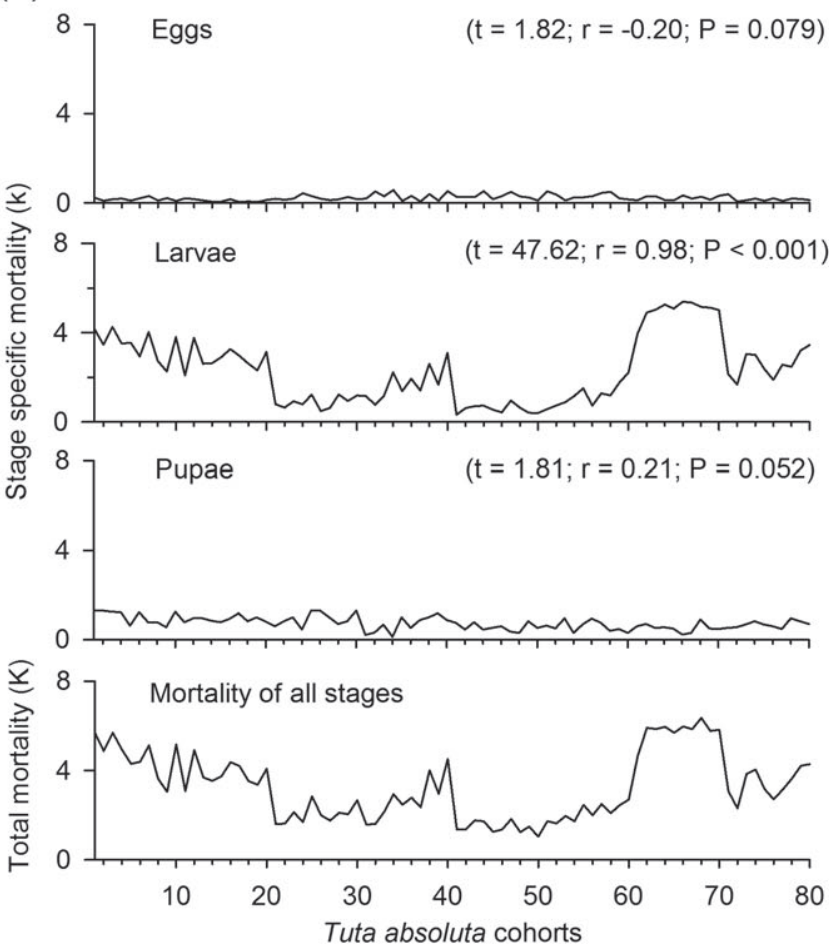

(B)
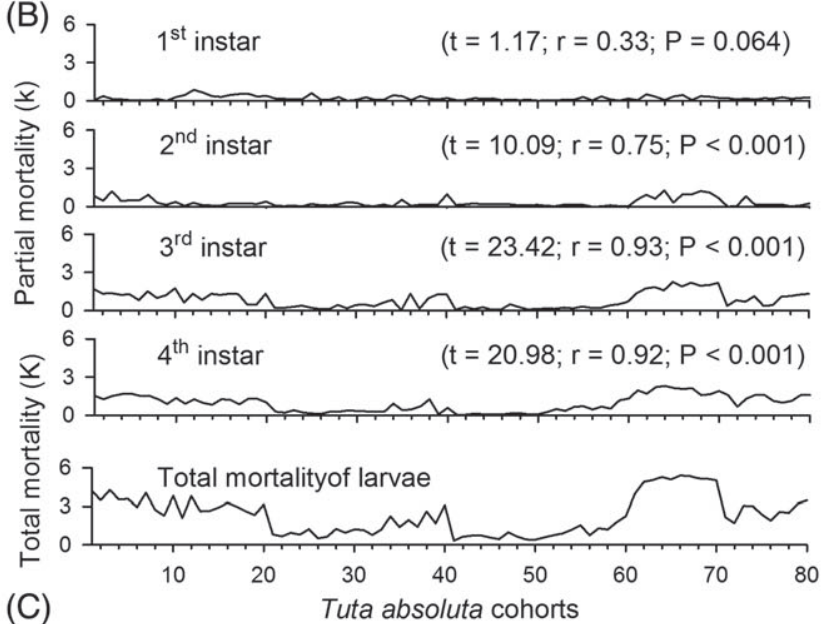

(C)

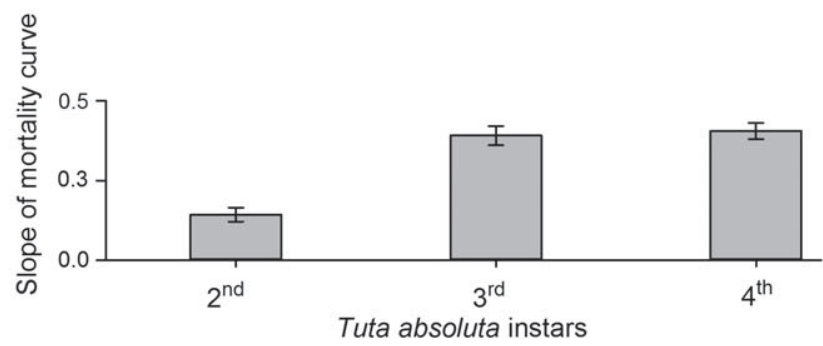

Figure 1. Determination of the critical phase and critical stage for Tuta absoluta mortality: (A) correlation of mortality at each T. absoluta life stage with total mortality of all immature stages combined; (B and C) correlations and regression curves of mortality of larvae in the first, second, third and fourth instar larval stages with total mortality. The confidence intervals for each regression curve were calculated at $95 \%$ probability.

immature stages of insects, our results show a higher vulnerability of the larval stage to the action of these factors. The $T$. absoluta larval period is longer ( $8-32$ days) than the egg phase (4-8 days) or the pupal phase (4-18 days). ${ }^{39}$ Thus, the larval stage presents greater risk of mortality due to longer exposure to mortality factors. These results corroborate with studies by Pereira et al. ${ }^{18}$ and Gonring et al..$^{33}$ These authors found higher susceptibility of the larval stages of Diaphania sp. and Leucoptera coffeella to natural mortality factors in cucumber and coffee crops, respectively.

Another important mortality factor for the insect was rainfall. Rainfall can cause egg and larval mortality due to mechanical damage from the impact of the rain drops or by drowning. Insects that are endophytic can be killed by drowning due to flooding of mines by rainfall, the entry and accumulation of water is proportional to the size of the mine. Third and fourth instar T. absoluta larvae create large mines in tomato leaves and therefore may be more vulnerable to death by drowning.

Predatory wasps were a critical mortality component for third and fourth instar larvae. Larger larvae have higher body mass and may be more compensatory to these wasps. The high predation exerted by Vespidae may be due to previous experience, distribution and abundance of prey. ${ }^{36}$ Social wasps can be opportunistic and generalist predators that often return to hunt at sites that presented previous hunting success and may feed repeatedly on the 
(A)

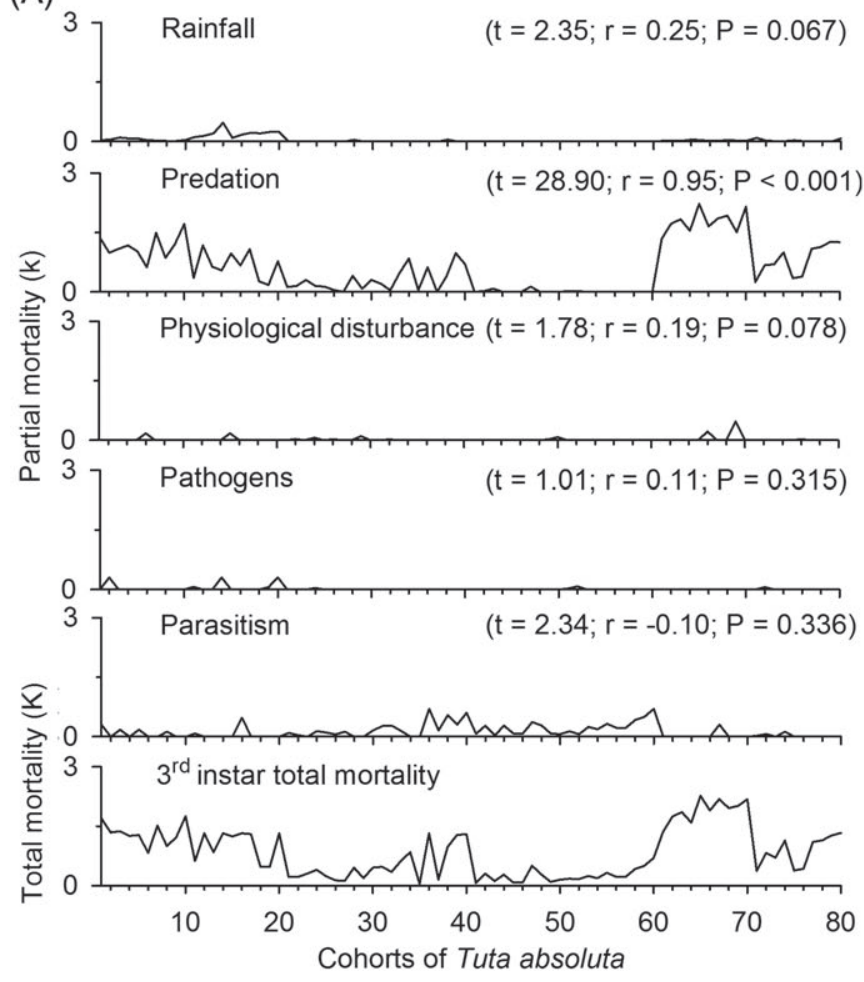

(B)

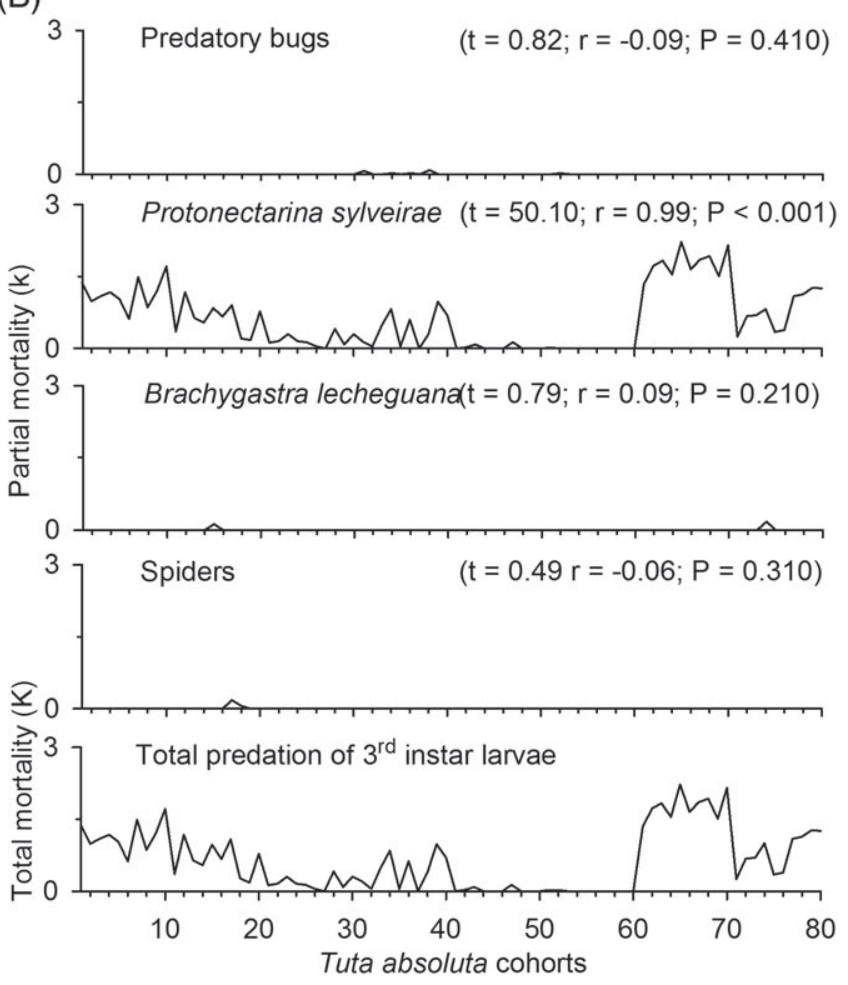

Figure 2. Determination of the key mortality factors occurring during the third instar larval stage of Tuta absoluta: (A) correlation between mortality factors and total mortality; (B) correlations of mortality caused by specific predators with total predation. The confidence intervals for each regression curve were calculated at $95 \%$ probability.

(A)

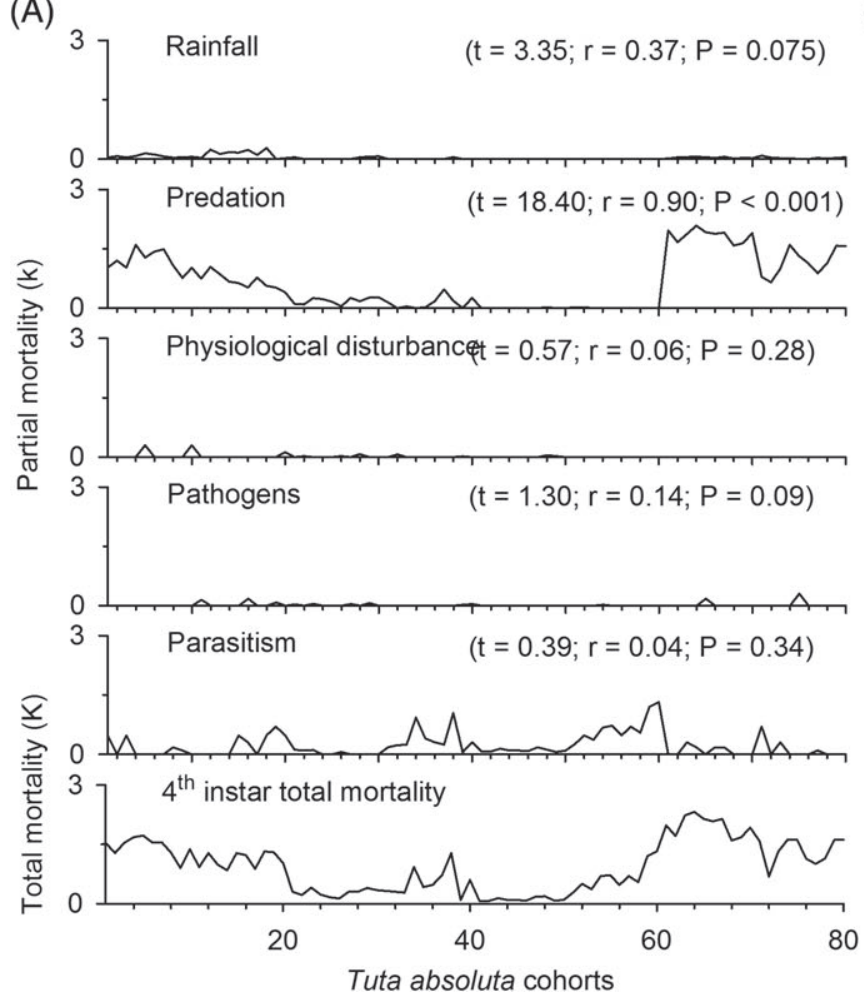

(B)

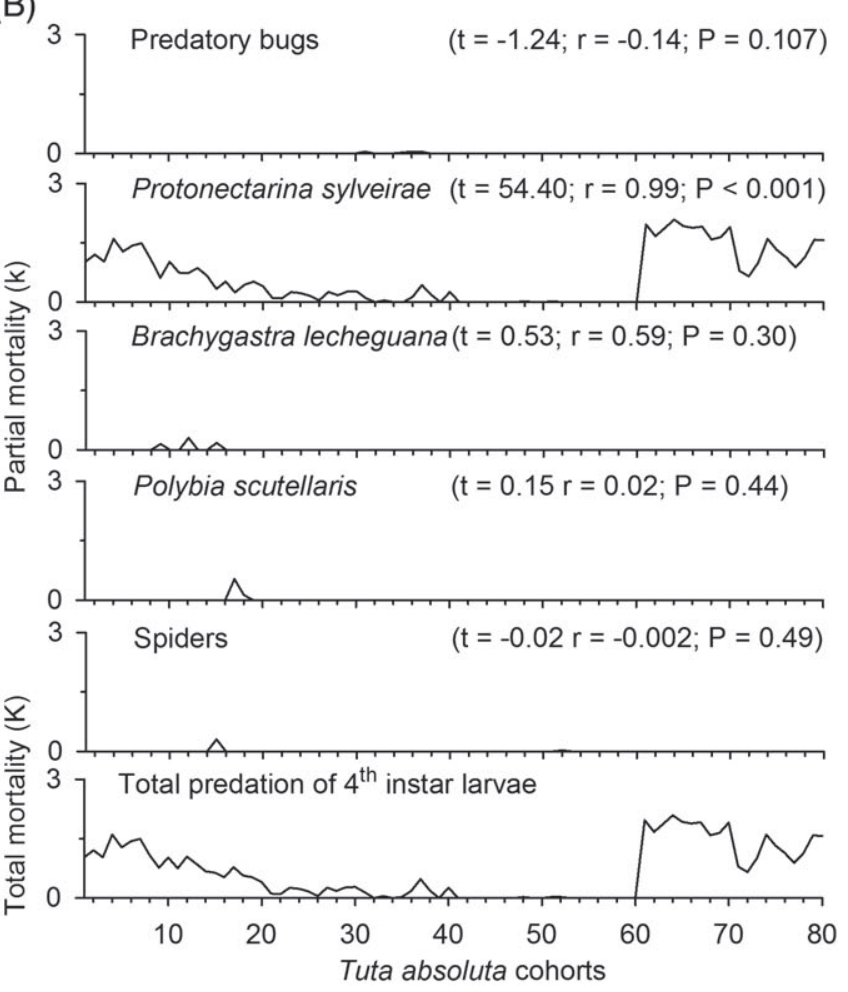

Figure 3. Determination of key mortality factors for fourth instar larvae of Tuta absoluta: (A) correlation between mortality factors and total mortality; (B) correlations of mortality caused by specific predators with total predation. The confidence intervals for each regression curve were calculated at $95 \%$ probability. 
same species of prey, behaving as facultative specialists. Therefore the success of foraging increases with age and experience of the wasp. ${ }^{40-42}$ The high predation rate exerted by $P$. sylveirae could also be related to the distribution and frequency of wasp nests in the locality where we carried out this study. Protonectarina sylveirae has a broad geographic distribution throughout South America, from Brazil to Argentina, although it is not found in the Amazon region of Brazil. This species builds very large and perennial arboreal nests and form colonies with large populations. ${ }^{43-45}$ In Brazil, the sites of open-field tomato crops used here coincided with the occurrence of $P$. sylveirae colonies. ${ }^{2,46}$ At other sites or in other countries, different natural enemies and other environmental factors may play a role in T. absoluta population regulation. ${ }^{37,38}$

The physical characteristics of the plant can also affect foraging by natural enemies. ${ }^{46}$ The size, architecture, leaf area, and trichomes of the host plant (glandular and non-glandular) may alter searching efficiency and capture of the pest by natural enemies. Natural enemies take more time to find prey in plants with complex architecture (highly branching) than with simple architecture. ${ }^{47-49}$ Tomato plants have a simple architecture which appears not to negatively affect the foraging success of natural enemies.

Host plant volatile compounds may have a direct effect on pest and natural enemy behavior. Studies have demonstrated that volatile compounds released by damaged plants can attract arthropod natural enemies of herbivores. ${ }^{50,51}$ Predatory wasps prefer to forage on plants damaged by insects rather than on undamaged plants, while wasps may also mark plants or leaves to help in prey localization. ${ }^{48}$

In this context, the adoption of practices that contribute to increasing the diversity of agroecosystems is important to conserve and enhance natural enemy populations. Therefore, insecticides which are less toxic to natural enemies should be chosen to control T. absoluta. Furthermore, these products should be used at times when natural enemies are less active in the field, especially considering that predatory wasps are more active foraging in tomato fields between 10:00 and 16:00 h. ${ }^{23,52,53}$

In conclusion, we found that natural control factors are important in the regulation of T. absoluta populations in tomato fields. The critical phase of the life cycle is the larval phase and the critical stages are the third and fourth instars. Predation by wasps is a very important mortality factor and is fundamental for the natural management of T. absoluta populations in tomato fields. Control strategies need to take into account these findings, in order to reduce pest populations without the random application of insecticides, as is the current scenario in Brazil.

\section{ACKNOWLEDGEMENTS}

The authors thank Dr Angélica Maria Penteado Martins Dias (parasitoids identification), Dr Paulo Sérgio Fiuza (predatory bugs identification), and Dr Ayr de Moura Bello (beetles identication). The authors also thank CNPq and FAPEMIG for providing resources, the Post-Graduate Programs in Entomology and Plant Science of Federal University of Viçosa. LB MCP and RIS are CNPq research fellows.

\section{REFERENCES}

1 Picanço MC, Leite GLD, Guedes RNC and Silva EA, Yield loss in trellised tomato affected by insecticidal sprays and plant spacing. Crop Prot 17:447-452 (1998)

2 Silva GA, Picanço MC, Bacci L, Crespo ALB, Rosado JF and Guedes RNC, Control failure likelihood and spatial dependence of insecticide resistance in the tomato pinworm, Tuta absoluta. Pest Manag Scl 67:913-920 (2011).
3 Biondi A, Guedes RNC, Wan FH and Desneux N, Ecology, worldwide spread, and Management of the Invasive South American Tomato Pinworm, Tuta absoluta: past, present, and future. Annu Rev Entomol 63:239-258 (2018). https://doi.org/10.1146/annurev-ento$031616-034933$.

4 Desneux N, Wajnberg E, Wyckhuys KAG, Burgio G, Arpaia S, Narváez-Vasquez CA et al., Biological invasion of European tomato crops by Tuta absoluta: ecology, history of invasion and prospects for biological control. J Pest Sci 83:197-215 (2010).

5 Morais GJ and Normanha-Filho JÁ, Surto de Scrobipalpula absoluta (Meyrick) em tomateiro no Trópico Semi-Árido. Pesq Agro Bras 17:503-504 (1982).

6 Garcia-Marí F and Vercher R, Descripcion, origem y expansion de Tuta absoluta (Lepidoptera: Gelechiidae). Phytoma España 217:16-20 (2010).

7 Zappala L, Bernardo U, Biondi A, Cocco A, Deliperi S, Delrio G et al., Recruitment of native parasitoids by the exotic pest Tuta absoluta in Southern Italy. B Insectol 65:51-61 (2012).

8 Campos MR, Biondi A, Adiga A, Guedes RNC and Desneux N, From the western Palaearctic region to beyond: Tuta absoluta 10 years after invading Europe. J Pest Sci 90:787-796 (2017).

9 Moreira LA, Picanço MC, Silva GA, Semeão AA, Casali VWD, Campos MR et al., Antibiosis of eight Lycopersicon genotypes to Tuta absoluta (Lepidoptera: Gelechiidae). R Ceres 56:283-287 (2009).

10 Caparros Megido R, Brostaux Y, Haubruge E and Verheggen FJ, Propensity of the tomato leafminer, Tuta absoluta (Lepidoptera: Gelechiidae), to develop on four potato plant varieties. Am J Potato Res 90:255-260 (2013).

11 Lietti MM, Botto E and Alzogaray RA, Insecticide resistance in argentine populations of Tuta absoluta (Meyrick) (Lepidoptera: Gelechiidae). Neotrop Entomol 34:113-119 (2005).

12 Gontijo PC, Picanço MC, Pereira EJG, Martins JC, Chediak M and Guedes RNC, Spatial and temporal variation in the control failure likelihood of the tomato leaf miner, Tuta absoluta. Ann Appl Biol 162:50-59 (2013).

13 Siqueira HA, Guedes RN and Picanço MC, Insecticide resistance in populations of Tuta absoluta (Lepidoptera: Gelechiidae). Agric Forest Entomol 2:147-153 (2000).

14 Miranda MMM, Picanço MC, Zanuncio JC and Guedes RNC, Ecological life table of Tuta absoluta (Meyrick) (Lepidoptera: Gelechiidae). Biocontrol Sci Technol 8:597-606 (1998).

15 Niedmann MB, Evaluacion de cepas nativas de Bacillus thuringiensis como una alternative de manejo integrado de la polilla del tome (Tuta absoluta Meyrick; Lepidoptera: Gelechiidae) en Chile. Agr Téc 66:235-246 (2006).

16 Luna MG, Sánchez NE and Pereyra PC, Parasitism of Tuta absoluta (Lepidoptera, Gelechiidae) by Pseudapanteles dignus (Hymenoptera, Braconidae) under laboratory conditions. Environ Entomol 36:887-893 (2007).

17 Luna MG, Wada VI, La Salle J and Sánchez NE, Neochrysocharis formosa (Westwood) (Hymenoptera: Eulophidae), a newly recorded parasitoid of the tomato moth, Tuta absoluta (Meyrick) (Lepidoptera: Gelechiidae), in Argentina. Neotrop Entomol 40:412-414 (2011).

18 Pereira EJG, Picanço MC, Bacci L, Della Lucia TMC, Silva EM and Fernandes FL, Natural mortality factors of Leucoptera coffeella (Lepidoptera: Lyonetiidae) on Coffea Arabica. Biocontrol Sci Technol 17:441-455 (2007).

19 Shalaby HH, Faragalla FH, El-Saadany HM and Ibrahim AA, Efficacy of three entomopathogenic agents for control the tomato borer, Tuta absoluta (Meyrick) (Lepidoptera: Gelechiidae). Nature Sci 11:63-72 (2013).

20 Harcourt DG, The development and use of life tables in the study of natural insect populations. Annu Rev Entomol 14:175-196 (1969).

21 Morris RF, Predictive population equations based on key factors. Mem Entomol Soc Can 32:6-21 (1963).

22 Southwood TRE, Ecological Methods with Particular References to the Study of Insect Populations, 2nd edn. Chapman \& Hall, New York, NY (1978).

23 Semeão AA, Martins JC, Picanço MC, Chediak M, Silva GA and Silva ÉM, Seasonal variation of natural mortality factors of the guava psyllid Triozoida limbata. Bull Entomol Res 102:1 - 11 (2012).

24 Gonring AHR, Sistemas de tomada de decisão para o manejo integrado de Tuta absoluta (Meyrick) na cultura do tomate [Tese de doutorado]. Universidade Federal de Viçosa, Viçosa (2004). 
25 Haji FNP, Parra JRP, Silva JP and Batista JGS, Biologia da traça-dotomateiro sob condições de laboratório. Pesq Agro Bra 23:107-110 (1988).

26 Southwood TRE and Hendersen PA, Ecological Methods, 3rd edn. Blackwell Science, Oxford (2000).

27 Mihsfeldt LH and Parra JRP, Biologia de Tuta absoluta (Meyrick, 1917) em dieta artificial. Sci Agric 56:769-776 (1999).

28 Moreau G, Eveleigh ES, Lucarotti CJ and Quiring DT, Ecosystem alteration modifies the relative strengths of bottom-up and top-down forces in a herbivore population. J Anim Ecol 75:853-861 (2006).

29 Leite GLD, Picanço MC, Bacci L and Gonring AHR, Dose-response regression lines of tridecan-2-one for Myzus persicae. AgroCiencia 15:135-138 (1999).

30 Isman MB, The role of botanical insecticides, deterrents and repellents in modern agriculture and an increasingly regulated world. Annu Rev Entomol 51:51-66 (2006).

31 Kos M, Broekgaarden C, Kabouw P, Lenferink KO, Poelman EH, Vet LEM et al., Relative importance of plant-mediated bottom - up and top - down forces on herbivore abundance on Brassica oleracea. Funct Ecol 25:1113-1124 (2011).

32 Gervassio S, Nadia G, Luna MG, Lee S, Salvo A and Sánchez NE, Trophic web associated with the South American tomato moth Tuta absoluta: implications for its conservation biological control in Argentina. Agric Forest Entomol 18:137-144 (2016).

33 Gonring AHR, Picanço MC, Guedes RNC and Silva EM, Natural biological control and key mortality factors of Diaphania hyalinata (Lepidoptera: Pyralidae) in cucumber. Biocontrol Sci Technol 13:361-366 (2003).

34 Wlby $\mathrm{A}$ and Orwin $\mathrm{KH}$, Herbivore species richness, composition and community structure mediate predator richness effects and top-down control of herbivore biomass. Oecologia 172:1167-1177 (2013).

35 Barros EC, Bacci L, Picanco MC, Martins JC, Rosado JF and Silva GA, Physiological selectivity and activity reduction of insecticides by rainfall to predatory wasps of Tuta absoluta. J Environ Sci Heal B 50:45-54 (2015).

36 Richter MR, Social wasp (hymenoptera: Vespidae) foraging behavior. Annu Rev Entomol 45:121-150 (2000).

37 Urbaneja A and González-Cabrera J, Arno J and Gabarra. Prospects for the biological control of Tuta absoluta in tomatoes of the Mediterranean basin Pest Manag Sci 68:1215-1122 (2012).

38 Zappala L, Biondi A, Alma A, Al-Jboory IJ, Arno J, Bayram A et al., Natural enemies of the South American moth, Tuta absoluta, in Europe, North Africa and Middle East, and their potential use in pest control strategies. J Pest Sci. 86:635-647 (2013).
39 Martins JC, Picanço MC, Bacci L, Guedes RNC, Santana PA, Ferreira DO et al., Life table determination of thermal requirements of the tomato borer Tuta absoluta. J Pest Sci 89:897-908 (2016).

40 O'Donnell S and Jeanne RL, Lifelong patterns of forager behaviour in a tropical swarm-founding wasp: effects of specialization and activity level on longevity. Anim Behav 44:1021-1027 (1992).

41 Richter RMA, Hunting wasp interactions: influence of prey size, arrival order, and wasp species. Ecology 71:1018-1030 (1990).

42 Cornelius ML, Influence of caterpillar-feeding damage on the foraging behavior of the paper wasp Mischocyttarus flavitarsis (Hymenoptera: Vespidae). J Insect Behav 6:771 - 781 (1993).

43 Richards OW, The Social Wasps of the Americas, Excluding Vespinae. British Museum Press, London (1978).

44 Wenzel JW, A generic key to the nests of hornets, yellowjackets, and paper wasps worldwide (Vespidae: Vespinae, Polistinae). Am Mus Novit 3224:1 - 39 (1998).

45 Shima SN, Noll FB and Zucchi R, Influence of the colony cycle on physiological and morphological caste variation in the perennial neotropical swarm-founding social wasp, Protonectarina sylveirae (Hymenoptera, Vespidae, Epiponini). Sociobiology 42:449-466 (2003).

46 da Silva M, Noll FB and Castro ACM-C, Phylogeographic analysis reveals high genetic structure with uniformphenotypes in the paper wasp Protonectarina sylveirae (Hymenoptera: Vespidae). PLoS ONE 13:1-25 (2018). https://doi.org/10.1371/journal.pone.019442

47 Andow DA and Prokrym DR, Plant structural complexity and host-finding by a parasitoid. Oecologia 82:162-165 (1990).

48 Geitzenauer HL and Bernays EA, Plant effects on prey choice by a vespid wasp, Polistes arizonensis. Ecol Entomol 21:227-234 (1996).

49 Pearson $\mathrm{DE}$, Invasive plant architecture alters trophic interactions by changing predator abundance and behavior. Oecologia 159:549-558 (2009).

50 Unsicker SB, Kunert G and Gershenzon J, Protective perfumes: the role of vegetative volatiles in plant defense against herbivores. Curr Opin Plant Biol 12:479-485 (2009).

51 Fragstein M, Holighaus G, Schütz S and Tscharntke T, Weak defence in a tritrophic system: olfactory response to salicylaldehyde reflects prey specialization of potter wasps. Chemoecology 23:181-190 (2013).

52 Bacci L, Picanço MC, Rosado JF, Silva GA, Crespo ALB, Pereira EJG et al., Conservation of natural enemies in brassica crops: comparative selectivity of insecticides in the management of Brevicoryne brassicae (Hemiptera: Sternorrhyncha: Aphididae). Appl Entomol Zool 119:103-113 (2009).

53 Picanço MC, Oliveira IR, Rosado JF, Silva FM, Gontijo PC and Silva RS, Natural biological control of Ascia monuste by the social wasp Polybia ignobilis (Hymenoptera: Vespidae). Sociobiology 56:67-76 (2010). 